\title{
Spatial patterns of endemism in shallow-water reef fish populations of the Northwestern Hawaiian Islands
}

\author{
Edward E. DeMartini ${ }^{1, *}$, Alan M. Friedlander ${ }^{2}$ \\ ${ }^{1}$ NOAA Fisheries, Pacific Island Fisheries Science Center, 2570 Dole Street, Honolulu, Hawaii 96822-2396, USA \\ ${ }^{2}$ NOAA, National Ocean Service, National Centers for Coastal Ocean Science - Biogeography Program, and The Oceanic \\ Institute, Makapuu Point/41-202 Kalanianaole Highway, Waimanalo, Hawaii 96795, USA
}

\begin{abstract}
The spatial distribution and magnitude of endemism in shallow-water $(<18 \mathrm{~m})$ reef fishes of the 10 Northwestern Hawaiian Islands (NWHI) are described in terms of occurrence, and numerical and biomass densities, using a series of diver-observation surveys conducted during September/October 2000, 2001, and 2002. Based on species-presence in our surveys, we found endemism to be equal ( $20.6 \%$ using all available data) for fishes in the NWHI and the Main Hawaiian Islands ( $\mathrm{MHI}_{i} 20.9 \%$ ). On average, percentage endemism was much higher based on the biomass $(37 \%)$ and numerical densities $(52 \%)$ of endemics, increased with latitude, and was especially pronounced at the 4 northernmost reefs that are the most ancient emergent geological features of the archipelago. Endemic reef fishes were appreciably smaller bodied than non-endemics within the NWHI. Median body size did not vary with latitude and longitude for either endemics or nonendemics, negating environmental effects. Reef fish populations at higher latitude reefs included larger proportions of young-of-year (YOY) recruits. YOY length frequencies did not differ for most species between northern and southern reefs, suggesting that a seasonal lag in spawning and recruitment at higher latitudes cannot explain the greater YOY densities observed there. Disproportionate recruitment at higher-latitude reefs may be related to better growth and survivorship after settlement onto reefs, higher levels of within-reef and regional reseeding at higher latitudes, or other factors. Resolution of these issues will be difficult, but it is profoundly important to the future siting of no-take Marine Protected Areas (MPAs) within the NWHI Coral Reef Ecosystem Reserve and to the rational conservation and management of reef fish resources throughout the Hawaiian Archipelago.
\end{abstract}

KEY WORDS: Endemism · Dispersal · Recruitment - Replenishment · Advection · Larval transport · Coral reef fishes $\cdot$ Northwestern Hawaiian Islands

\section{INTRODUCTION}

Endemism is a key attribute of biotic communities that is generally a great concern of conservation ecology. Recently, the endemism of coral reef fish faunas (Wellington \& Victor 1992, Victor \& Wellington 2000), particularly those of isolated oceanic islands (Robertson 2001), has been a popular research topic for several complementary reasons. One reason of general biogeographic interest is that speciation and the origin and maintenance of biodiversity are un- doubtedly related to degrees of isolation and endemism. Another reason, relevant to major current research on coral reef fishes, is that isolated endemic faunas provide excellent subjects (Robertson 2001) for testing current competing hypotheses of whether localized reseeding of primarily closed populations or non-localized recruitment among open populations more importantly influences the metapopulation dynamics of coral reef fishes (Caley et al. 1996, Cowen 2002, Doherty 2002, Hixon \& Webster 2002, Mora \& Sale 2002). 


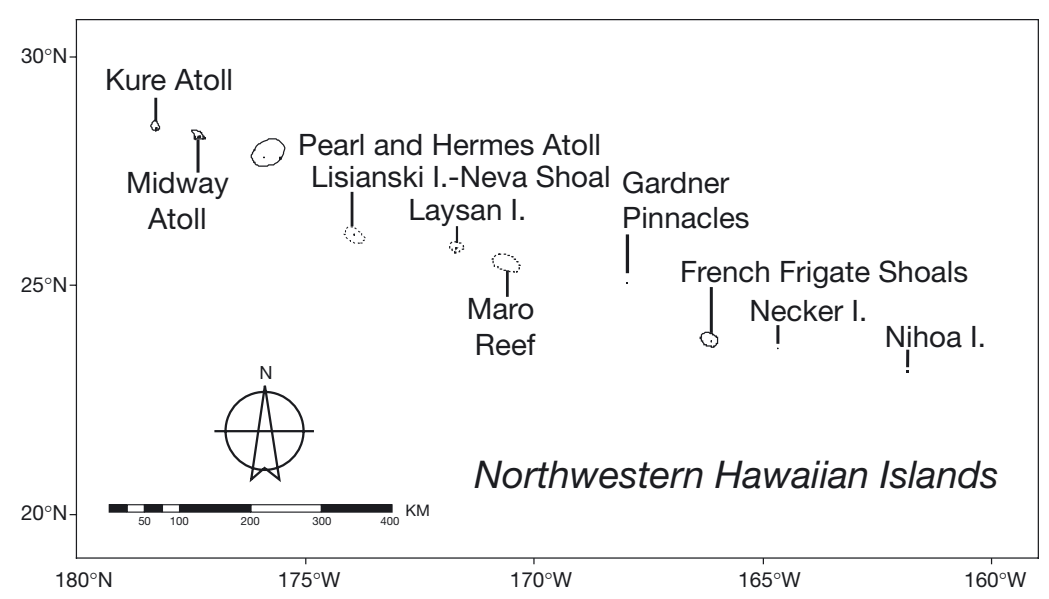

Fig. 1. Northwestern Hawaiian Islands showing positions of the 10 emergent basaltic pinnacle reefs, coral cays, and atolls surveyed during September/October 2000, 2001 and 2002

The Hawaiian Archipelago spans 10 degrees of latitude and 23 degrees of longitude, extending $2600 \mathrm{~km}$ in a SE-NW direction. It includes the Main Hawaiian Islands (MHI) and the Northwestern Hawaiian Islands (NWHI). The MHI extend from the most southeastern island of Hawaii ('Big Island', $19.7^{\circ} \mathrm{N}, 155.6^{\circ} \mathrm{W}$ ), the most recent of the 8 geologically young $(<1$ to 6 million years old [my]), human-populated, high or windward islands, to Kauai. The NWHI extend from Nihoa to Kure Atoll $\left(29.6^{\circ} \mathrm{N}, 178.9^{\circ} \mathrm{W}\right)$ at the NW extreme of the mostly uninhabited and low-lying, leeward islands (Fig. 1). The latter is a chain of 10 emergent basaltic pinnacles, coral cays, and both open (partially drowned) atolls and classical atolls (semi-closed, with 1 or several passes) that represent the remnants of ancient ( 7 to $28 \mathrm{my}$ ) islands of volcanic origin that originally developed over the tectonic 'hot spot' that now exists ca. $50 \mathrm{~km}$ southeast of the Big Island (Juvik \& Juvik 1998). The Hawaiian Island chain is among the most isolated on earth and exhibits the highest level of marine fish endemism of any archipelago in the Pacific (Randall 1995, 1998, Randall \& Earle 2000, Allen 2002). Although huge, the individual islands and reefs of the archipelago lie only ca. 85 to 210 (mean 150) km distant from one another (Table 1), so it is the archipelago, not individual reefs, which is extremely isolated.

A major current concern of conservation ecologists and resource managers associated with the Northwestern Hawaiian Islands Coral Reef Ecosystem Reserve, a Marine Protected Area (MPA) that includes a number of no-take marine reserves, is the nature of the unknown biological linkages of reef fishes and other biota between the NWHI and the MHI. Although the shallow-water $(<18 \mathrm{~m})$ reef fish populations of the NWHI are still relatively pristine (largely because isolation has hindered their exploitation), the reef fishes of the MHI, especially apex predators, are presently overexploited (Friedlander \& DeMartini 2002). Sustainable exploitation of MHI reef fishes and the conservation of their counterparts in the NWHI requires information on demographic linkages and other key elements determining the stock structure of their populations. To date

Table 1. Descriptive statistics for stations surveyed at the 10 emergent basaltic pinnacle reefs, coral cays, and atolls during September/October periods of 2000, 2001, and 2002. Sites are ordered geographically from NW to SE. MHI: Main Hawaiian Islands

\begin{tabular}{|c|c|c|c|c|c|c|c|}
\hline Reef & $\begin{array}{l}\text { Latitude } \\
\qquad\left({ }^{\circ} \mathrm{N}\right)\end{array}$ & $\begin{array}{l}\text { Longitude } \\
\qquad\left({ }^{\circ} \mathrm{W}\right)\end{array}$ & Reef type(s) & $\begin{array}{l}\text { Reef area (ha) } \\
<10 \text { fathoms }\end{array}$ & $\begin{array}{l}\text { Distance in } \mathrm{km} \text { to } \\
\text { nearest emergent reef }\end{array}$ & $\begin{array}{l}\text { No. of } \\
\text { stations }\end{array}$ & $\begin{array}{l}\text { Area (ha) } \\
\text { surveyed }\end{array}$ \\
\hline Kure Atoll (KUR) & 29.6 & 178.9 & Atoll & 6791 & 100 (MID) & 59 & 17.7 \\
\hline Midway Atoll (MID) & 29.3 & 177.9 & Atoll & 8000 & 100 (KUR) & 37 & 11.1 \\
\hline $\begin{array}{l}\text { Pearl and Hermes } \\
\text { Atoll (PHR) }\end{array}$ & 28.8 & 176.3 & Atoll & 40336 & 150 (MID) & 76 & 22.8 \\
\hline $\begin{array}{l}\text { Lisianski Island-Neva } \\
\text { Shoal (LIS) }\end{array}$ & 26.8 & 174.4 & $\begin{array}{l}\text { Coral cay, } \\
\text { uplifted bank }\end{array}$ & 20270 & 200 (LAY) & 30 & 9.0 \\
\hline Laysan Island (LAY) & 26.7 & 172.2 & Coral cay & 2367 & 85 (MAR) & 20 & 6.0 \\
\hline Maro Reef (MAR) & 26.2 & 170.9 & $\begin{array}{l}\text { Open atoll, } \\
\text { reticulated reef system }\end{array}$ & 18762 & 85 (LAY) & 43 & 12.9 \\
\hline $\begin{array}{l}\text { Gardner Pinnacles } \\
\text { (GAR) }\end{array}$ & 26.0 & 168.4 & Pinnacle & 34 & 180 (FFS) & 10 & 3.0 \\
\hline $\begin{array}{l}\text { French Frigate } \\
\text { Shoals (FFS) }\end{array}$ & 24.5 & 166.3 & $\begin{array}{l}\text { Part drowned atoll, } \\
\text { pinnacle }\end{array}$ & 46921 & 135 (NEC) & 74 & 22.2 \\
\hline Necker Island (NEC) & 24.2 & 165.0 & Pinnacle & 213 & 135 (FFS) & 16 & 4.8 \\
\hline Nihoa Island (NIH) & 23.8 & 162.1 & Pinnacle & 55 & 210 (Niihau in MHI) & 11 & 3.3 \\
\hline All & - & - & - & 135749 & - & 376 & 112.8 \\
\hline
\end{tabular}


these types of data are lacking for the NWHI, although recruitment data provide preliminary insights for 2 of the 10 emergent reefs (DeMartini 2004). Molecular evaluations using gene products (starch gel electrophoresis of enzymes) and mtDNA have been unable to detect appreciable genetic variation among NWHI and MHI populations, including those of shallow reef fishes (e.g. Shaklee 1984). Early evaluations of mtDNA and nuclear DNA also have been largely unsuccessful at detecting substantive genetic structuring, either because isolation has been insufficient to hinder gene flow or because available technology was then too coarse to detect the small, but potentially meaningful genetic differences now amenable to evaluation of spatial patterns using genomic fingerprinting of nuclear DNA (Palumbi 2003).

In this paper, we provide several types of data that begin to address the question of how the geographic distribution of endemism might provide insights into the demography and stock structure of the reef fishes of the Hawaiian archipelago. First, we present new observations on the levels of endemism of the shallow reef fishes of the NWHI based on numerical and biomass density estimates for these fishes at each of the 10 emergent reefs, cays, and atolls. Previous evaluations of endemism in Hawaiian reef fishes have been restricted to species presence (e.g. see Randall 1996) or have semi-quantitatively summarized patterns of relative abundance (Hourigan \& Reese 1987). We emphasize the densities of numerically and biomass-dominant species and endemic and non-endemic assemblages, and relate densities to latitude in order to explore geographic patterns for both endemics and non-endemics. Second, we examine key life-history and other attributes (median and maximum body sizes, proportion and size distributions of young-of-year [YOY] recruits) to provide insights into the potential mechanisms underlying the observed patterns. Third, we discuss several possible, non-mutually exclusive hypotheses for the observed spatial patterns of recruitment and endemism. We conclude with a brief discussion of the implications of some of our results for the future stewardship of shallow reef-fish resources within the Hawaiian Islands.

\section{MATERIALS AND METHODS}

Field surveys. All density estimates were provided by in situ diver surveys (belt transects of standard area), conducted using scuba and snorkel during daylight (08:00 to $17: 00 \mathrm{~h})$, swum at a constant speed $\left(5 \mathrm{~m} \mathrm{~min}^{-1}\right)$ within station-areas (stations). Stations were sited randomly within major habitat strata (fringing reefs, spanning both windward and leeward expo- sures at non-atolls, and forereefs, backreefs, and lagoonal reefs at atolls). Sampling effort, defined as the number of stations (area surveyed), was proportional $\left(\mathrm{r}_{\mathrm{s}}=+0.88, \mathrm{p}<0.001\right)$ to total surveyable $(<18 \mathrm{~m}$ depth $)$ reef area, and averaged ca. 35 stations (combined 2.1 ha), ranging from a low of 10 stations ( $0.6 \mathrm{ha}$ ) at tiny Gardner to highs of 74 stations (4.4 ha) at relatively huge Pearl and Hermes and French Frigate Shoals (FFS; Table 1). Each station estimate was the summed, length-specific tally of three $25 \mathrm{~m}$-long transects. Each transect was surveyed by a pair of divers on an initial, 1-way swim of $2 \times 4 \mathrm{~m}=8 \mathrm{~m}$ width for large-bodied ( $\geq 20 \mathrm{~cm}$ total length, TL) fish, followed immediately by a return swim of $2 \times 2 \mathrm{~m}=4 \mathrm{~m}$ width, centered along the same transect swath, for small-bodied $(<20 \mathrm{~cm} \mathrm{TL})$ fish. The 3 transects at each station tracked a single, representative isobath (at 3 to $18 \mathrm{~m}$ depth, depending on station) and were spaced ca. $10 \mathrm{~m}$ apart to avoid recounting fishes attracted to divers. Stations therefore spanned ca. 100 linear meters of reef. Length-specific counts were tallied by length bins whose interval increased with size from $1 \mathrm{~cm}$ (at $<5 \mathrm{~cm}$ TL) through $5 \mathrm{~cm}(5$ to $50 \mathrm{~cm})$ to $10 \mathrm{~cm}(>50 \mathrm{~cm})$; body lengths were estimated by reference to size standards (Friedlander \& DeMartini 2002). Mean densities per reef were estimated based on all stations at that reef. Speciespresence data on transects were supplemented by qualitative 'roving diver' searches, centered along the major axis of transects and extending ca. $15 \mathrm{~m}$ to either side, that increased the total area used to characterize the station species list on average ca. 5-fold from 600 to $3000 \mathrm{~m}^{2}$.

All fishes encountered were tallied by species or lowest recognizable taxon and classified as either endemic or non-endemic according to Randall (1996), Randall \& Clements (2001), and Randall \& Myers (2002). Our criterion for endemism was a geographic distribution limited to the Hawaiian Archipelago and Johnston Island; we did not consider subspecific status as evidence for endemism (DeMartini 2004). Our main evaluation did not include 17 non-endemic and 1 endemic apex predator (Table 2) because the jacks and sharks that dominate apex predator biomass are generally wide-ranging transients, not reef residents. Apex predators were, however, included in a complementary evaluation for comparison. Estimates for the remaining tallies of non-apex predatory fishes were adjusted for the potential complication resulting from unavoidable pooling of endemic and non-endemic species into generic or high-order taxa because certain species were indistinguishable underwater. Only major species (i.e. those contributing at least $1 \%$ to numerical or biomass totals) were considered individually in order to avoid the undue influence of rare species for which density estimates were less precise. 
Table 2. Phylogenetic list of the 17 non-endemic and a single endemic (bold type) species of apex predatory sharks and bony fishes recorded at 376 stations at 10 Northwestern Hawaiian Island (NWHI) reefs during September/October periods of 2000, 2001 and 2002. Two other species of apex predators known from the Hawaiian archipelago-the golden jack or ulua pa'opa'o Gnathanodon speciosus and the thicklipped jack or butaguchi Pseudocaranx dentex-were not encountered on quantitative belt transects

\begin{tabular}{|c|c|c|c|}
\hline Family & Common name & Hawaiian name & Scientific name \\
\hline Carcharhinidae & Grey reef shark & Mano & Carcharhinus amblyrhynchos \\
\hline Carcharhinidae & Galapagos shark & Mano & Carcharhinus galapagensis \\
\hline Carcharhinidae & Whitetip reef shark & Mano lalakea & Triaenodon obesus \\
\hline Muraenidae & Giant moray & Puhi & Gymnothorax javanicus \\
\hline Belonidae & Houndfish & 'aha & Tylosurus crocodilus \\
\hline Serranidae & Hawaiian grouper & Hapu'u & Epinephelus quernus \\
\hline Carangidae & Barred jack & Ulua & Carangoides ferdau \\
\hline Carangidae & Giant trevally & Ulua aukea & Caranx ignobilis \\
\hline Carangidae & Black jack & Ulua la‘uli & Caranx lugubris \\
\hline Carangidae & Bluefin trevally & Omilu & Caranx melampygus \\
\hline Carangidae & Island jack & Ulua & Carangoides orthogrammus \\
\hline Carangidae & Bigeye jack & Pake ulua & Caranx sexfasciatus \\
\hline Carangidae & Rainbow runner & Kamanu & Elagatis bipinnulata \\
\hline Carangidae & Leatherback jack & Lai & Scomberoides lysan \\
\hline Carangidae & Greater amberjack & Kahala & Seriola dumerili \\
\hline Lutjanidae & Grey snapper & Uku & Aprion virescens \\
\hline Sphyraenidae & Great barracuda & Kaku & Sphyraena barracuda \\
\hline Scombridae & Island skipjack & Kawakawa & Euthynnus affinis \\
\hline
\end{tabular}

Statistical analyses. Effects of endemism were evaluated at the level of fish assemblages and for major individual species. Detrended Correspondence Analyses (DCA; Gauch 1982) of numerical and biomass densities were used to describe spatial relationships among NWHI fish assemblages. Estimates were lntransformed and rare species (those occurring in $<20 \%$ of the number of stations at which the most common species occurred) were downweighted. The amount that a species was downweighted was inversely related to its frequency of occurrence (Kovach 1995). Reef-means of numerical and biomass densities were also used to describe the importance of major taxa (those cumulatively comprising 84 and $82 \%$ of the numbers and biomass, respectively, of all fishes) that individually represented a minimum of $1 \%$ of either/or both density totals. Densities and body sizes were related to latitude using univariate linear correlation. Either Spearman's nonparametric correlation or Pearson's parametric correlation using rank-transformed data (Conover \& Iman 1981) was used to evaluate geographic relations for variables (percentage endemism, recruit index) that were nonlinearly related to latitude, depending on the degree of nonlinearity. Two-way Kolmogorov-Smirnov (K-S) tests (Siegel \& Castellan 1988) were used to compare length-frequency distributions between endemic and non-endemic species and other groupings. The relative contribution of recently recruited individuals within reef populations of each major taxon (and collectively within endemic and nonendemic groups) was calculated as the ratio of YOY to larger-sized individuals comprising the numerical density estimates ('recruit index', RI). YOY were distinguished from older-stage individuals based on the species-specific body size thresholds listed by DeMartini et al. (2002). These values ranged greatly among fishes from $4 \mathrm{~cm}$ TL in a few small-bodied species (like the endemic pufferfish Canthigaster jactator and the nonendemic damselfish Chromis vanderbilti) to 15 to $20 \mathrm{~cm}$ in a number of non-endemic species with pelagic juveniles (e.g. some balistids, all kyphosids, and the oplegnathids). Nominal (signed) differences and trends in correlations were compared between groups of endemics and non-endemics using $2 \times 2$ contingency Chi-square tests (Siegel \& Castellan 1988). A Bonferroni correction $\left(\mathrm{p}_{\text {crit }}=0.05 / \mathrm{m}\right.$, where $\mathrm{m}=$ number of tests within a series; Manly 1991) was used to adjust for distortion of alpha levels by multiple testing. Data were analyzed using version 8 of PC SAS for Windows (SAS Institute 1999).

\section{RESULTS}

\section{Species presence and relative abundance}

Subtropical and temperate species were observed on the shallow reefs of the northern portion of the archipelago, even though these species occur at much greater depths southward. Perhaps the most conspicuous manifestation of this pattern was the presence, at the shallow depths surveyed, of 2 species of Hawaiian 
endemics: the masked angelfish Genicanthus personatus (at the 3 atolls farthest to the NW: Kure, Midway, and Pearl and Hermes) and the Hawaiian grouper or 'hapu'u' Epinephelus quernus (at Kure and Midway only). These 2 species and the non-endemic spinyface soldierfish Pristilepis oligolepis are known to occur only at greater than conventional scuba diving depths in the MHI (Randall 1996, Chave \& Malahoff 1998). Some species of non-endemics also occurred only at the northernmost atolls, or were notably more abundant there. One non-endemic from the western Pacific (the Japanese angelfish Centropyge interruptus) was seen only at Pearl and Hermes and Midway. Three other non-endemics, the banded knifejaw Oplegnathus fasciatus, the whiskered boarfish Evistias acutirostris, and the spinyface soldierfish (the latter 2 species antitropical in distribution), were encountered only at Kure and Midway. One other western Pacific non-endemic, the spotted knifejaw $O$. punctatus, was encountered more frequently and at greater abundances farther upchain in the archipelago. The Hawaiian morwong Cheilodactylus vittatus, an Indo-west Pacific species with an antitropical distribution, was more common and frequently encountered farthest upchain in the NWHI, especially at the 3 northernmost atolls, although it was common mid-chain at FFS and at Gardner Pinnacles.

Of greater ecological significance than occurrence patterns for particular species were species presencebased estimates of species richness and endemism and their pattern of variation among NWHI reefs. Totals of 48 endemic and 162 non-endemic species $(22.9 \%$ endemism) of reef fishes were encountered on transects at 372 stations covering 22.3 ha total transect area at the 10 reefs (Table 1). If qualitative survey data are included for all 376 stations, based on a total area searched at all reefs of $113 \mathrm{ha}$, this list increases to 52 endemics and 200 non-endemics (252 total species including apex predators, and comprising 7 sharks and rays and 245 bony fishes), equivalent to $20.6 \%$ endemism. The percentage of endemics increased if species frequency occurrence was considered-endemics represented $34 \%$ of all species-observations, and were $71 \%$ more frequently encountered than non-endemics if expectation is based on species presence, viewed over all reefs pooled $\left(2 \times 2 \chi^{2}=22.0 ; \mathrm{p}<0.001\right)$. Thus endemic species were more widely distributed and ubiquitous than non-endemics. Percentage endemism (excluding apex predators) based on frequency occurrence on transects ranged from 25 to $33 \%$ and averaged $30 \%$ among the 10 emergent NWHI reefs. Including apex predators in the species frequency occurrence tallies had minor effects on percentage endemism (mean $28 \%$; range 23 to $31 \%$ ). Species richness (including apex predators) on transects ranged from 99 at Necker Island to 155 at FFS and averaged

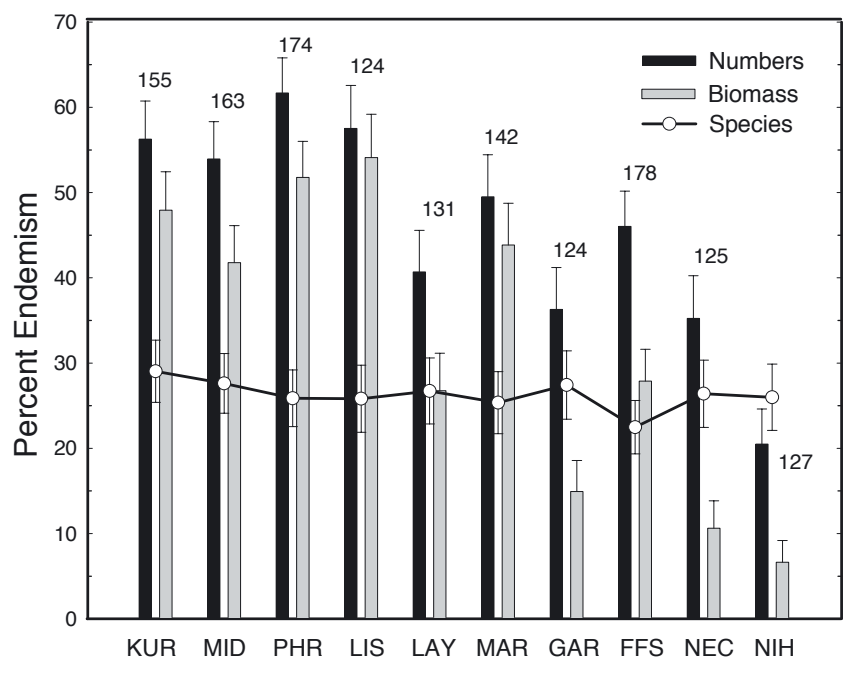

Fig. 2. Various measures of \% endemism (based on species occurrence, and on numerical and biomass densities) at each of 10 emergent Northwestern Hawaiian Island (NWHI) reefs, illustrating patterns of endemism with latitude. Occurrence data are indicated by line graph and density data by histograms. Vertical lines indicate SEs of estimates. Species richness (number of species) is noted by a number atop each set of histograms; see Table 1 for sampling effort (numbers of stations and areas surveyed) and reef abbreviations

121 species. Analogous values including qualitative searches ranged from 134 at Lisianski Island-Neva Shoal to 191 at FFS and averaged 157 species (Fig. 2). As one would expect based on species-area relations, species richness was greater at the more extensively surveyed, larger reefs $\left(r_{s}=+0.84, p=0.002\right)$, including but not limited to atolls with more complex habitat structure (Fig. 2). Percentage endemism based on species presence was unrelated to reef area $\left(r_{s}=-0.32, p=\right.$ 0.37 ), but endemism based on the density metrics described in the next section was correlated with total available reef area (both $r_{s}=+0.73, p=0.02$ ).

\section{Numerical and biomass densities}

Endemic and non-endemic species pooled into genera (primarily unidentifiable juvenile scarids) represented only 5 and $1 \%$ of total numerical and biomass densities, respectively, and were ignored in all subsequent analyses. Endemism averaged $52.0 \%$ among reefs (range 20.5 to $61.7 \%$ ) if gauged by numerical density (and apex predators are excluded), rather than using species presence (Fig. 2). Including apex predators had negligible influence on numerical endemism (mean $51.7 \%$; range 20.4 to $61.1 \%$ ). Using biomass density as currency, estimates of percentage endemism (excluding apex predators) were less than those based on numbers, but still remarkably high (mean 
$37 \%$, range 7 to $54 \%$; Fig. 2). Biomass was the only endemism metric that was appreciably affected by including largely non-endemic apex predators (mean $19 \%$; range 5 to $41 \%$ ). For our main comparison excluding apex predators, levels of endemism (numbers) were significantly (Wilcoxon signed-ranks test; $T=54, p=0.002$ ) greater than those based on species occurrence at the respective reef with the lone exception of Nihoa Island (Fig. 2). The analogous comparison for biomass was suggestive only ( $T=39, \mathrm{p}=0.14$ ).

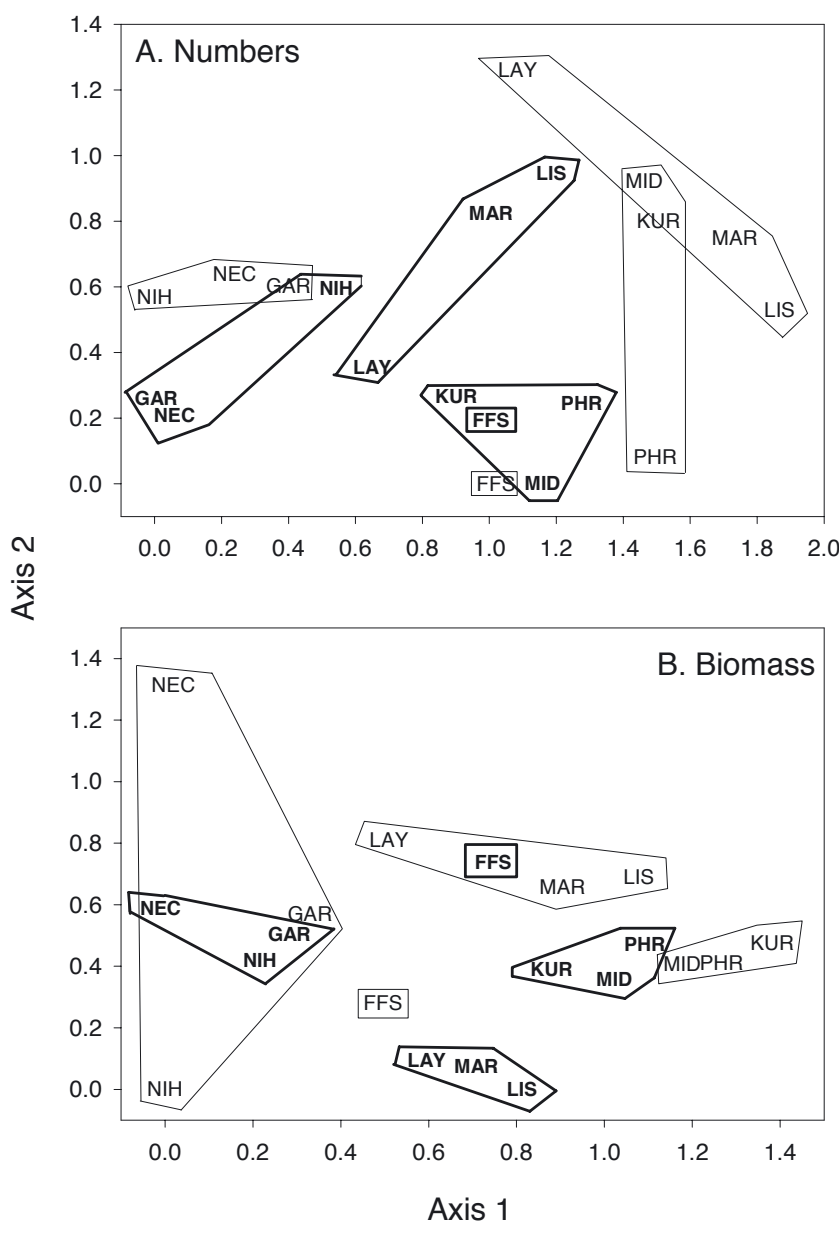

Fig. 3. Spatial clustering of (A) numerical and (B) biomass densities for endemic (bold) and non-endemic species-groupings, including all component species but with rare species down-weighted, among the 10 emergent Northwestern Hawaiian Island (NWHI) reefs, evaluated by detrended correspondence analysis. For numbers in Panel A, Axis 1: eigenvalue $=0.145, \%$ total variance $=31.5$ for endemics; eigenvalue $=0.297, \%$ total variance $=31.9$ for non-endemics; Axis 2 : eigenvalue $=0.067, \%$ total variance $=46.1$ for endemics; eigenvalue $=0.100, \%$ total variance $=42.6$ for non-endemics . For biomass in Panel B: Axis 1: eigenvalue $=0.091, \%$ total variance $=29.3$ for endemics ; eigenvalue $=0.183, \%$ total variance $=29.7$ for non-endemics; Axis 2: eigenvalue $=0.031$, $\%$ total variance $=39.2$ for endemics; eigenvalue $=0.093$, $\%$ total variance $=44.8$ for non-endemics. See Table 1 for reef abbreviations

\section{Spatial measures of endemism}

Percentage endemism of major species increased non-linearly with latitude (numerical density: $\mathrm{r}_{\mathrm{s}}=$ $+0.84, p=0.002$; biomass: $\left.r_{s}=+0.78, p<0.01\right)$, and was especially pronounced at the northernmost end of the archipelago (Fig. 2). No geographic pattern was evident for percentage endemism based on species presence $(\mathrm{p}>0.2)$ or for species richness (all species; $\mathrm{p}=$ 0.34; Fig. 2). All subsequent evaluations of endemism exclude apex predators unless specified otherwise.

Important spatial relationships were observed for more than just major species of endemics, however. Fish assemblage structure formed distinct clusters in ordination space for both endemic and non-endemic species based on latitudinal and geological reef groupings (Fig. 3). The first DCA axis showed a general shift in assemblage structure along a latitudinal gradient moving to the right from south to north. The more southern basalt islands of Necker, Nihoa, and Gardner Pinnacles formed unique clusters, as did the most northern atolls of Pearl and Hermes, Midway, and Kure. Lisianski-Neva Shoal, Laysan, and Maro Reef, all of which lie in the middle of the archipelago (Fig. 1), appear in ordination space between the southern and northern clusters. In all cases, FFS did not cluster according to any natural geological or latitudinal grouping. Endemic species showed higher concordance in both numerical and biomass densities, within island group cluster, compared to non-endemics.

\section{Biological attributes of endemic and non-endemic species}

Body size was the single most conspicuous life-history attribute that differed between endemic and nonendemic fishes. Values differed in parallel for known maximum and observed median body lengths, and averaged ca. $40 \%$ smaller (medians: 8 vs $13 \mathrm{~cm} \mathrm{TL;}$ maxima: 18 vs $30 \mathrm{~cm}$ TL) for endemic versus nonendemic species (Mann-Whitney $U$ - and K-S tests: both $\mathrm{p}<0.001$; Fig. 4A,B). Medians of known maxima and observed median body lengths of endemics and non-endemics remained the same even if the relatively few species of large-bodied apex predators (Table 2) were included.

A less obvious but perhaps more biologically meaningful attribute of endemics in the NWHI is the ratio of YOY to older-sized individuals comprising reef populations, and how this varies among geographic locales (Table 3, Fig. 5). RIs (all species) ranged from a low of 0.090 at Laysan Island to a high of 0.256 at LisianskiNeva Shoal, with a median of 0.163 among all 10 reefs. Analogous values were 0.193 and 0.155 for all 
endemics and non-endemics, respectively. Matched by reef, RIs for all endemics were greater (Wilcoxon signed-ranks test; $T=45, \mathrm{p}<0.05$ ) than those for all non-endemics. RIs trended positively but weakly with latitude for endemics as well as non-endemics (Fig. 5A). Parametric correlations using rank-transformed RIs, weighted by the square root of sample sizes, produced improved correlations for both numbers and biomass (Fig. 5B), although relations were still insignificant ( $p=0.24$ and 0.31 , respectively).

Length frequency distributions of YOY indicate that the increase in YOY proportions at higher latitudes was a latitudinal, rather than seasonal, effect. Length data were used to test the prediction that, if greater YOY densities simply reflected more recent recruitment at the 4 'northern' (higher latitude) reefs, YOY sizes should be skewed smaller in the north compared
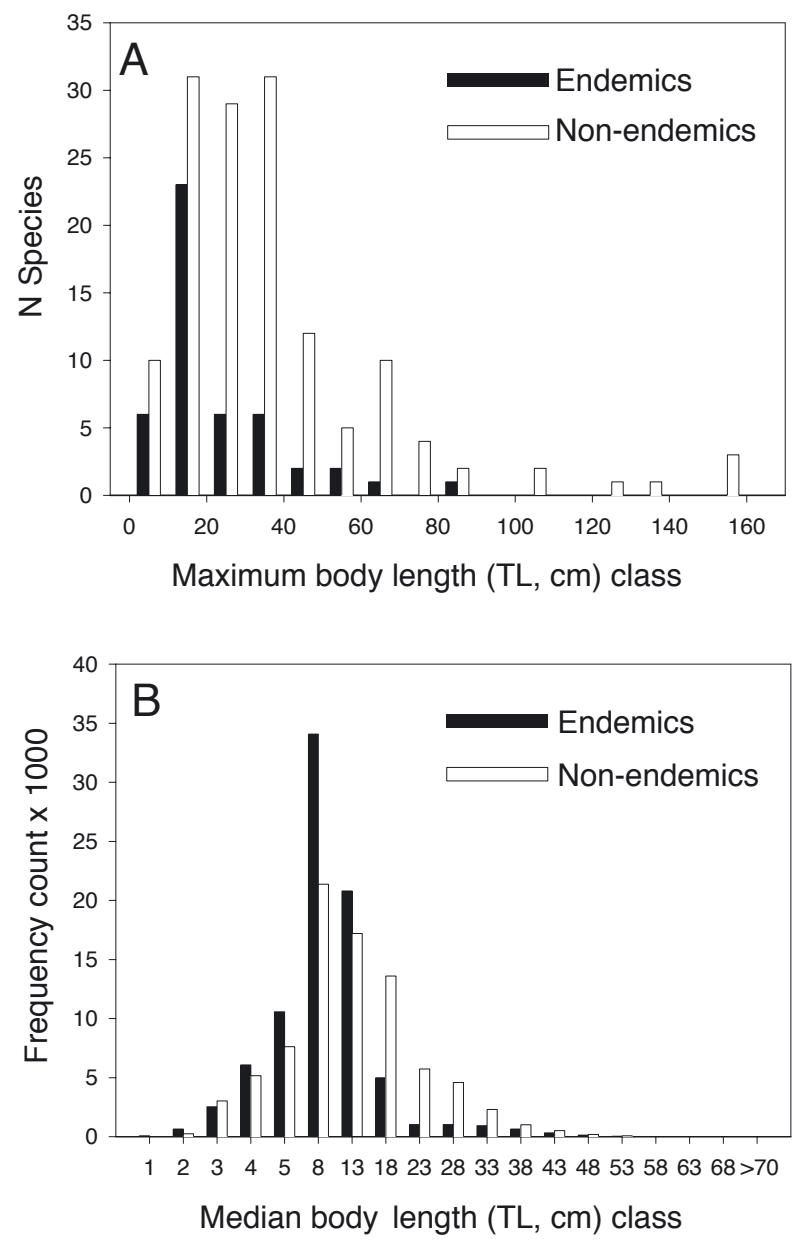

Fig. 4. Frequency distributions of (A) reported maximum and (B) observed median body lengths (both total length [TL] in $\mathrm{cm}$ ) for all species of endemic (black bars) versus nonendemic (white bars) reef fishes recorded on belt transects at a total of 372 stations at the 10 emergent Northwestern Hawaiian Island (NWHI) reefs surveyed during September/ October 2000, 2001 and 2002

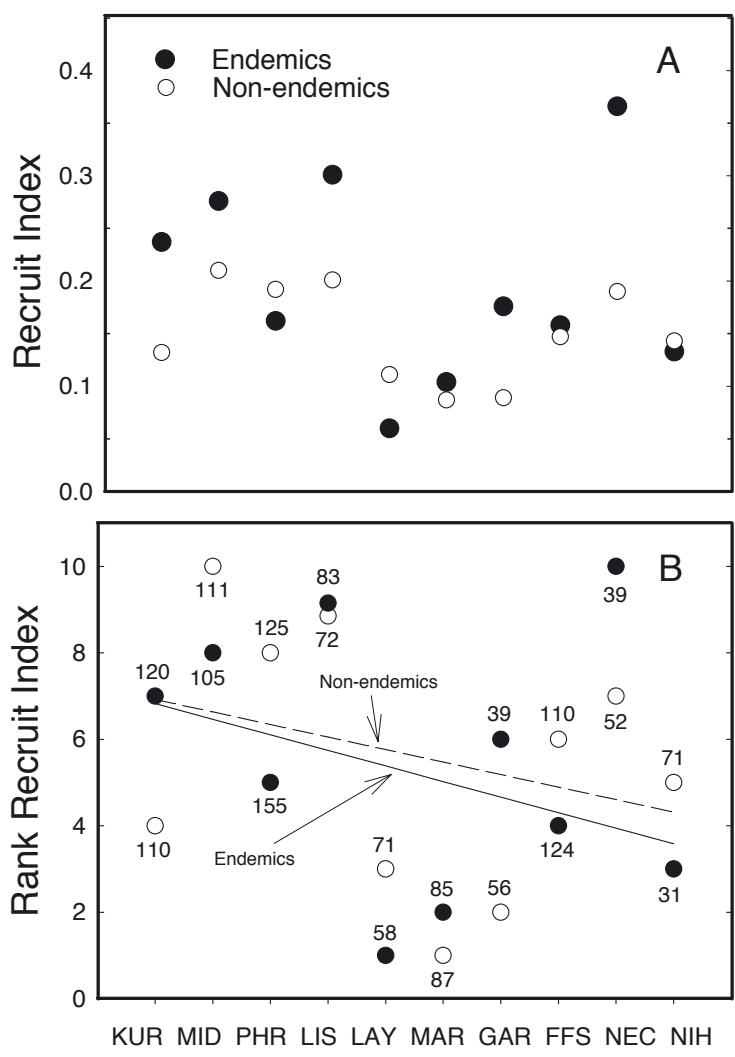

Fig. 5. Geographic patterns of (A) the Recruit Index (RI, ratio of young-of-year sized to larger individuals comprising a reef fish species population) and (B) rank RI, summarized for all pooled major species of endemic and non-endemic reef fishes, recorded at each of the 10 emergent NWHI reefs surveyed during September/October 2000, 2001 and 2002. Correlations in (B) were weighted by the square root of sample sizes (total numbers of fishes). See Table 1 for reef abbreviations

to the 6 'southern' reefs. Of the 14 endemic and 18 non-endemic species for which recruits were observed in both the north and south, the median body lengths of the YOY of only a single endemic (the wrasse Stethojulis balteata) and one non-endemic species (Mulloidichthys vanicolensis, a goatfish with pelagic juveniles) were nominally smaller at the 4 northern reefs (Fisher exact tests; both $\mathrm{p}>0.9$ ). Even though the pooled YOY of endemics were generally smaller in the north (K-S test, $\mathrm{p}<0.001$ ), only 2 species (the damselfish Chromis hanui and the ubiquitous wrasse Thalassoma duperrey) comprised $62 \%$ of the $4 \mathrm{~cm}$ length class that dominated the length distribution of endemics in the north (Fig. 6). Hence, the observed greater recruit densities at northern reefs were unlikely due to a temporal lag in spawning and recruitment at higher latitudes for most species.

Matched comparisons among endemic and nonendemic species within genera unfortunately were not 
Table 3. Summary statistics matrix for a 'recruit index' (RI; numerical density ratio of young-of-year [YOY] to larger-sized, older individuals comprising the reef population) for each of 41 (33 numerical density and/or 8 biomass density) major fish species (18 endemics, 23 non-endemics), each comprising $>1 \%$ of the respective density total, at each and all of the 10 emergent Northwestern Hawaiian Island (NWHI) reefs (ordered geographically) that were surveyed during September/October 2000, 2001 and 2002. Taxa are ordered by descending grand mean RI (all reefs pooled); $\mathrm{n}$ denotes total number of YOY plus older-stage fish tallied. Summary statistics for Spearman's rank correlation $\left(\mathrm{r}_{\mathrm{s}}\right)$ between RI and latitude are noted. Endemics are depicted in bold. Significance of $\mathrm{p}$-values reflects adjustment for multiple testing (see section 'Materials and methods', 'statistical analyses'). See Table 1 for reef abbreviations. ${ }^{*}$ sig: $\mathrm{p}<\mathrm{p}_{\text {crit }}=0.05 / \mathrm{m}$; ns: $\mathrm{p}>\mathrm{p}_{\text {crit }}$

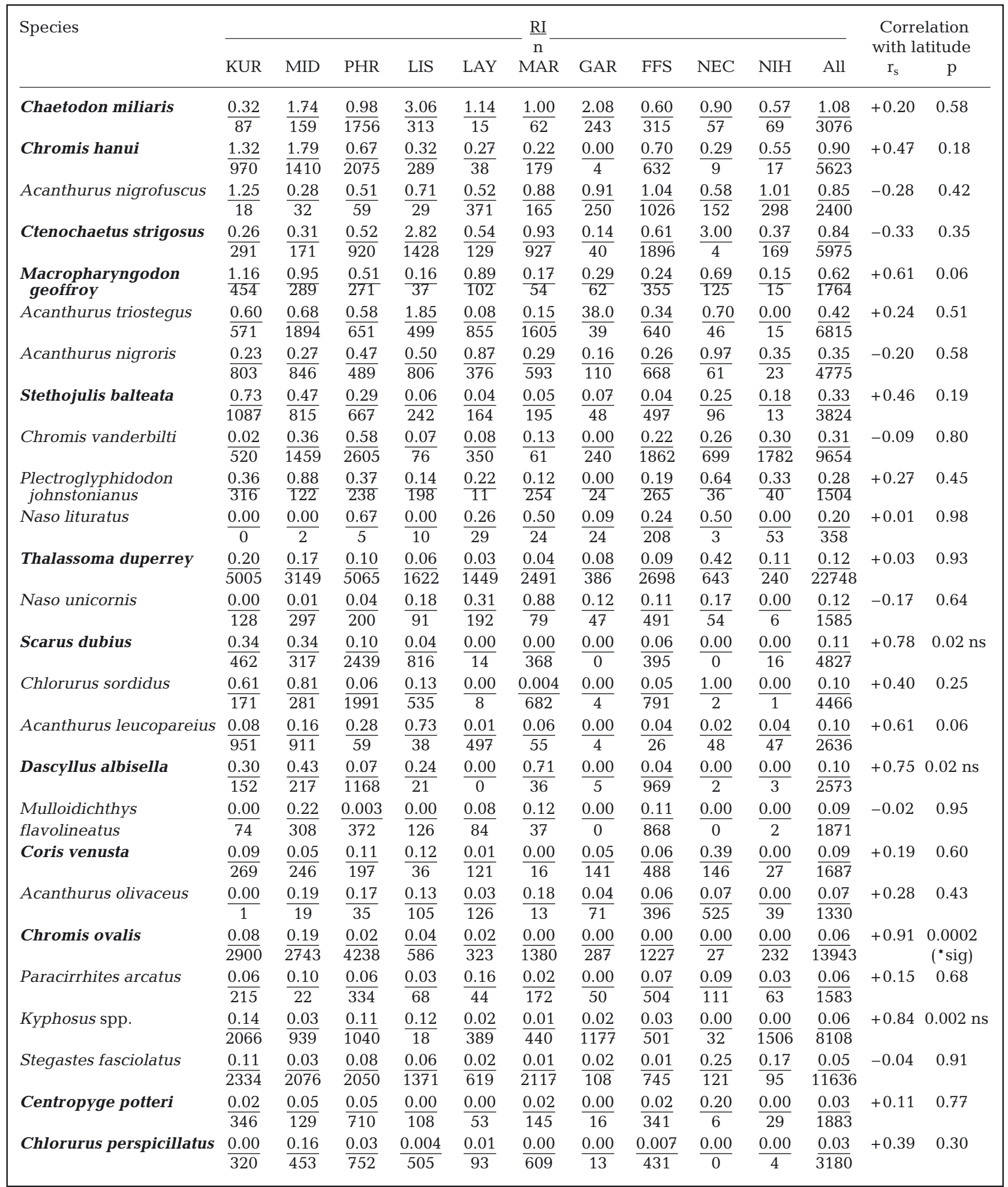


Table 3 (continued)

\begin{tabular}{|c|c|c|c|c|c|c|c|c|c|c|c|c|c|}
\hline Species & KUR & MID & PHR & LIS & LAY & MAR & GAR & FFS & NEC & $\mathrm{NIH}$ & All & $r_{s}$ & $\mathrm{p}$ \\
\hline Melichthys niger & $\frac{0.00}{4}$ & $\frac{0.00}{19}$ & $\frac{0.00}{76}$ & $\frac{0.25}{15}$ & $\frac{0.02}{46}$ & $\frac{0.03}{162}$ & $\frac{0.02}{55}$ & $\frac{0.03}{323}$ & $\frac{0.00}{112}$ & $\frac{0.00}{172}$ & $\frac{0.02}{984}$ & -0.12 & 0.74 \\
\hline $\begin{array}{l}\text { Mulloidichthys } \\
\text { vanicolensis }\end{array}$ & $\frac{0.007}{664}$ & $\frac{0.00}{169}$ & $\frac{0.00}{588}$ & $\frac{0.00}{26}$ & $\frac{0.00}{21}$ & $\frac{0.28}{23}$ & $\frac{0.00}{181}$ & $\frac{0.04}{792}$ & $\frac{0.00}{2}$ & $\frac{0.00}{15}$ & $\frac{0.02}{2481}$ & +0.04 & 0.91 \\
\hline Naso hexacanthus & $\frac{0.00}{0}$ & $\frac{0.00}{43}$ & $\frac{0.00}{17}$ & $\frac{0.00}{3}$ & $\frac{0.00}{0}$ & $\frac{0.00}{0}$ & $\frac{0.00}{37}$ & $\frac{0.00}{14}$ & $\frac{2.00}{3}$ & $\frac{0.00}{19}$ & $\frac{0.01}{136}$ & -0.41 & 0.36 \\
\hline Thalassoma ballieui & $\frac{0.03}{853}$ & $\frac{0.02}{450}$ & $\frac{0.01}{776}$ & $\frac{0.01}{363}$ & $\frac{0.00}{236}$ & $\frac{0.00}{337}$ & $\frac{0.00}{39}$ & $\frac{0.01}{272}$ & $\frac{0.00}{53}$ & $\frac{0.00}{22}$ & $\frac{0.01}{3401}$ & +0.70 & $0.02 \mathrm{~ns}$ \\
\hline Canthigaster jactator & $\frac{0.00}{103}$ & $\frac{0.00}{38}$ & $\frac{0.00}{133}$ & $\frac{.008}{135}$ & $\frac{0.00}{123}$ & $\frac{0.01}{145}$ & $\frac{0.00}{16}$ & $\frac{0.02}{462}$ & $\frac{0.00}{42}$ & $\frac{0.00}{17}$ & $\frac{0.01}{1214}$ & -0.17 & 0.64 \\
\hline Bodianus bilunulatus & $\frac{0.00}{190}$ & $\frac{0.008}{130}$ & $\frac{0.02}{259}$ & $\frac{0.00}{113}$ & $\frac{0.02}{55}$ & $\frac{0.008}{124}$ & $\frac{0.00}{26}$ & $\frac{0.00}{245}$ & $\frac{0.04}{55}$ & $\frac{0.00}{30}$ & $\frac{0.01}{1227}$ & -0.01 & 0.98 \\
\hline Coris flavovittata & $\frac{0.02}{61}$ & $\frac{0.01}{76}$ & $\frac{0.00}{90}$ & $\frac{0.00}{9}$ & $\frac{0.00}{8}$ & $\frac{0.00}{8}$ & $\frac{0.00}{1}$ & $\frac{0.00}{20}$ & $\frac{0.00}{2}$ & $\frac{0.00}{0}$ & $\frac{0.01}{275}$ & +0.73 & $0.03 \mathrm{~ns}$ \\
\hline Parupeneus multifasciatus & $S \frac{0.00}{64}$ & $\frac{0.00}{107}$ & $\frac{0.00}{290}$ & $\frac{0.006}{179}$ & $\frac{0.00}{135}$ & $\frac{0.00}{149}$ & $\frac{0.00}{62}$ & $\frac{0.008}{388}$ & $\frac{0.00}{101}$ & $\frac{0.00}{62}$ & $\frac{0.0+}{1537}$ & -0.12 & 0.74 \\
\hline Abudefduf abdominalis & $\frac{0.00}{76}$ & $\frac{0.00}{603}$ & $\frac{0.00}{894}$ & $\frac{0.00}{204}$ & $\frac{0.00}{81}$ & $\frac{0.00}{55}$ & $\frac{0.00}{7}$ & $\frac{0.00}{3}$ & $\frac{0.00}{0}$ & $\frac{0.00}{0}$ & $\frac{0.00}{1923}$ & - & - \\
\hline Calatomus zonarchus & $\frac{0.00}{52}$ & $\frac{0.00}{29}$ & $\frac{0.00}{27}$ & $\frac{0.00}{1}$ & $\frac{0.00}{9}$ & $\frac{0.00}{10}$ & $\frac{0.00}{4}$ & $\frac{0.00}{24}$ & $\frac{0.00}{6}$ & $\frac{0.00}{2}$ & $\frac{0.00}{164}$ & - & - \\
\hline Lutjanus kasmira & $\frac{0.00}{0}$ & $\frac{0.00}{1}$ & $\frac{0.00}{0}$ & $\frac{0.00}{0}$ & $\frac{0.00}{123}$ & $\frac{0.00}{0}$ & $\frac{0.00}{0}$ & $\frac{0.00}{1216}$ & $\frac{0.00}{0}$ & $\frac{0.00}{270}$ & $\frac{0.00}{1610}$ & - & - \\
\hline Monotaxis grandoculis & $\frac{0.00}{0}$ & $\frac{0.00}{0}$ & $\frac{0.00}{0}$ & $\frac{0.00}{3}$ & $\frac{0.00}{83}$ & $\frac{0.00}{15}$ & $\frac{0.00}{1}$ & $\frac{0.00}{91}$ & $\frac{0.00}{18}$ & $\frac{0.00}{16}$ & $\frac{0.00}{227}$ & - & - \\
\hline Naso brevirostris & $\frac{0.00}{1}$ & $\frac{0.00}{1}$ & $\frac{0.00}{28}$ & $\frac{0.00}{9}$ & $\frac{0.00}{143}$ & $\frac{0.00}{56}$ & $\frac{0.00}{50}$ & $\frac{0.00}{10}$ & $\frac{0.00}{61}$ & $\frac{0.00}{0}$ & $\frac{0.00}{359}$ & - & - \\
\hline Oplegnathus punctatus & $\frac{0.00}{19}$ & $\frac{0.00}{15}$ & $\frac{0.00}{7}$ & $\frac{0.00}{0}$ & $\frac{0.00}{10}$ & $\frac{0.00}{5}$ & $\frac{0.00}{28}$ & $\frac{0.00}{3}$ & $\frac{0.00}{0}$ & $\frac{0.00}{7}$ & $\frac{0.00}{94}$ & - & - \\
\hline Priacanthus meeki & $\frac{0.00}{167}$ & $\frac{0.00}{467}$ & $\frac{0.00}{543}$ & $\frac{0.00}{18}$ & $\frac{0.00}{183}$ & $\frac{0.00}{4}$ & $\frac{0.00}{23}$ & $\frac{0.00}{92}$ & $\frac{0.00}{1}$ & $\frac{0.00}{1}$ & $\frac{0.00}{1499}$ & - & - \\
\hline All 18 Endemic taxa & $\frac{0.234}{13655}$ & $\frac{0.279}{11761}$ & $\frac{0.163}{22721}$ & $\frac{0.298}{6733}$ & $\frac{0.055}{3141}$ & $\frac{0.103}{7021}$ & $\frac{0.197}{1335}$ & $\frac{0.159}{11117}$ & $\frac{0.379}{1218}$ & $\frac{0.136}{876}$ & $\frac{0.193}{79578}$ & +0.21 & 0.56 \\
\hline All 23 Non-endemic taxa & $\frac{0.137}{9110}$ & $\frac{0.229}{9693}$ & $\frac{0.194}{11393}$ & $\frac{0.235}{4318}$ & $\frac{0.119}{4567}$ & $\frac{0.087}{6831}$ & $\frac{0.089}{2588}$ & $\frac{0.146}{12073}$ & $\frac{0.183}{2240}$ & $\frac{0.150}{4561}$ & $\frac{0.160}{67374}$ & +0.22 & 0.53 \\
\hline
\end{tabular}
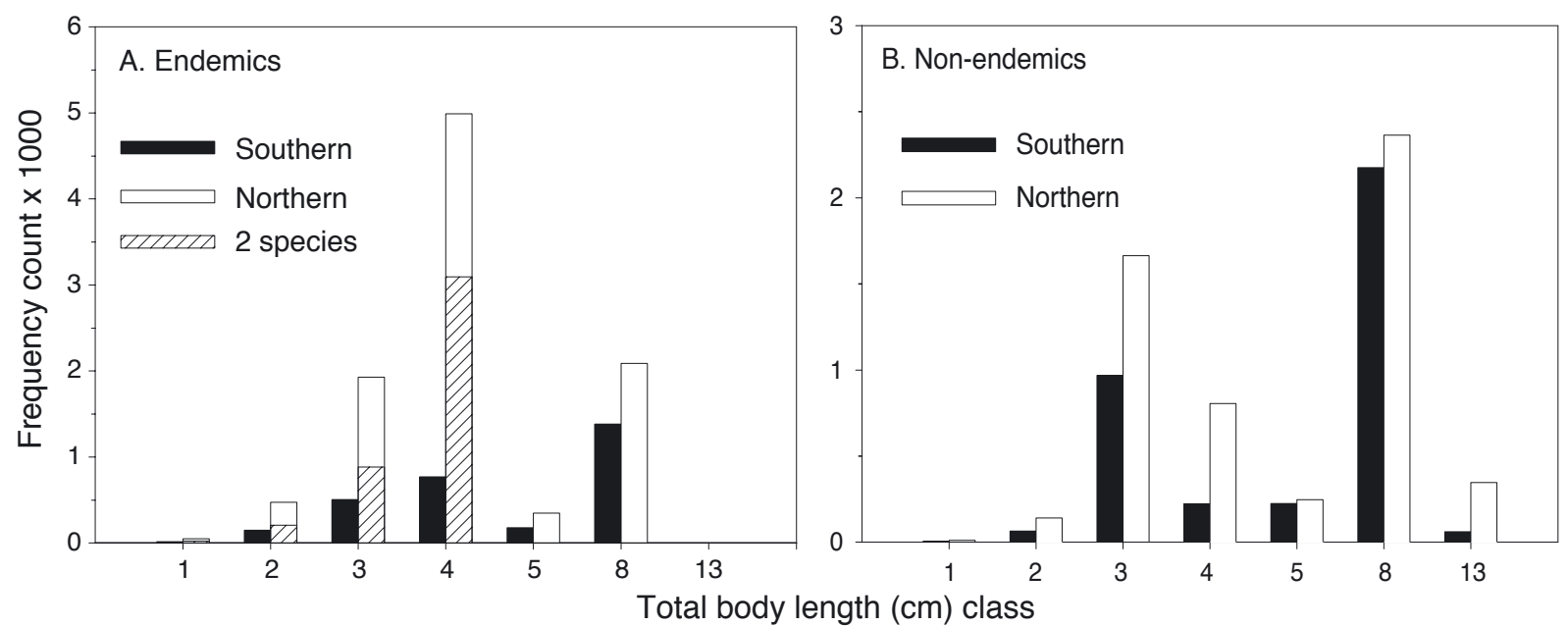

Fig. 6. Body size (total length [TL] in cm) frequency distributions of (A) endemic and (B) non-endemic young-of-the-year (YOY) fishes observed at the 4 'northern' reefs (Kure, Midway, Pear and Hermes atolls, Lisianski Island-Neva Shoal; white bars) with high Recruit Indexes (RIs) overlaid (offset) against YOY TL frequencies observed during September/October 2000,2001 and 2002 at the other 6 'southern' reefs (black bars) with relatively low average RIs. The disproportionate contribution of 2 species (see section 'Biological attributes of endemic and non-endemic species') to endemics at northern reefs is indicated by hatching 
Table 4. Data classification and Chi-square test results evaluating signed (positive, negative) correlations and trends in recruit index (RI) versus latitude for component species of endemic and non-endemic taxa

\begin{tabular}{|llllc|}
\hline & \multicolumn{3}{c|}{ Distribution of } \\
& $\begin{array}{l}\text { correlations/trends } \\
\text { Pos }\end{array}$ & Neg & Both & Chi-square \\
statistics
\end{tabular}

replicable over genera because only a single genus (Chromis) comprised both endemic and non-endemic species whose abundance was sufficient for analysis. Within this genus, the RIs of one non-endemic (C. vanderbilti) trended negatively with latitude, and those of 2 endemics $(C$. hanui, $C$. ovalis) were each at least nominally related to latitude (Table 3 ).

RI data were too variably distributed among reefs to reasonably analyze geographic relations for species separately, but the relative frequency of positive and negative signed correlations could be evaluated for the suite of taxa using the Chi-square statistic. Nominal correlations between RI and latitude were significantly and disproportionately positive for endemics among major taxa (Table 4). The only significant species-level correlation between RI and latitude was for Chromis ovalis (Table 3).

Several interesting latitudinal patterns (or lack of pattern) in body size and life-stage-specific abundance also were noted. First, average body size of pooled endemics and non-endemics was generally unrelated to latitude. This resulted from differences between the 2 biogeographic classes: median body size of olderstage fishes did not vary with latitude for endemics $\left(\mathrm{r}_{\mathrm{s}}=-0.27, \mathrm{p}=0.45\right)$, and trended more strongly towards an inverse relation (contrary to the expectation of larger body sizes at higher latitudes) for nonendemics $\left(r_{s}=-0.72, p=0.02\right.$, ns after correction for multiple-testing) (Fig. 7A). Nominal correlations between body size and latitude for older-stages of major taxa tested individually were insignificant for all except the non-endemic surgeonfish Acanthurus leucopareius $\left(\mathrm{r}_{\mathrm{s}}=-0.86, \mathrm{p}=0.001\right)$ and the distributions of positive and negative trends were equivalent for endemics ( 7 positive, 8 negative) and non-endemics ( 9 positive, 13 negative; $\chi^{2}<0.01, \mathrm{p}>0.9$ ).

Second, there was no geographic pattern to the numerical density of older-stage fishes for pooled major species of non-endemics $\left(r_{s}=-0.27, p=0.45\right)$, although a strong positive relationship between olderstage density and latitude existed for endemics $\left(r_{s}=+0.92, p=0.0002 ;\right.$ Fig. 7B). Recruit density tended to increase with latitude for major species of endemics $\left(\mathrm{r}_{\mathrm{s}}=+0.65, \mathrm{p}<0.05\right)$ but was unrelated to latitude for non-endemics $\left(\mathrm{r}_{\mathrm{s}}=-0.04, \mathrm{p}=0.91\right)$. Nominal correlations between density and latitude were generally positive (13 of 18 cases) for the older-stages of major endemic taxa and significantly so for 4 species (Chromis ovalis, the parrotfish Chlorurus perspicillatus, Thalassoma ballieui, T. duperrey). This contrasted with no significant species correlations and a lack of latitudinal pattern for non-endemics (11 positives vs 12 negatives; $\chi^{2}=1.57,0.3>p>0.2$ ).

\section{DISCUSSION}

\section{Relations among various measures of endemism}

Comparisons of endemism among island and other faunas are usually limited to species presence, undoubtedly because quantitative density and abun-
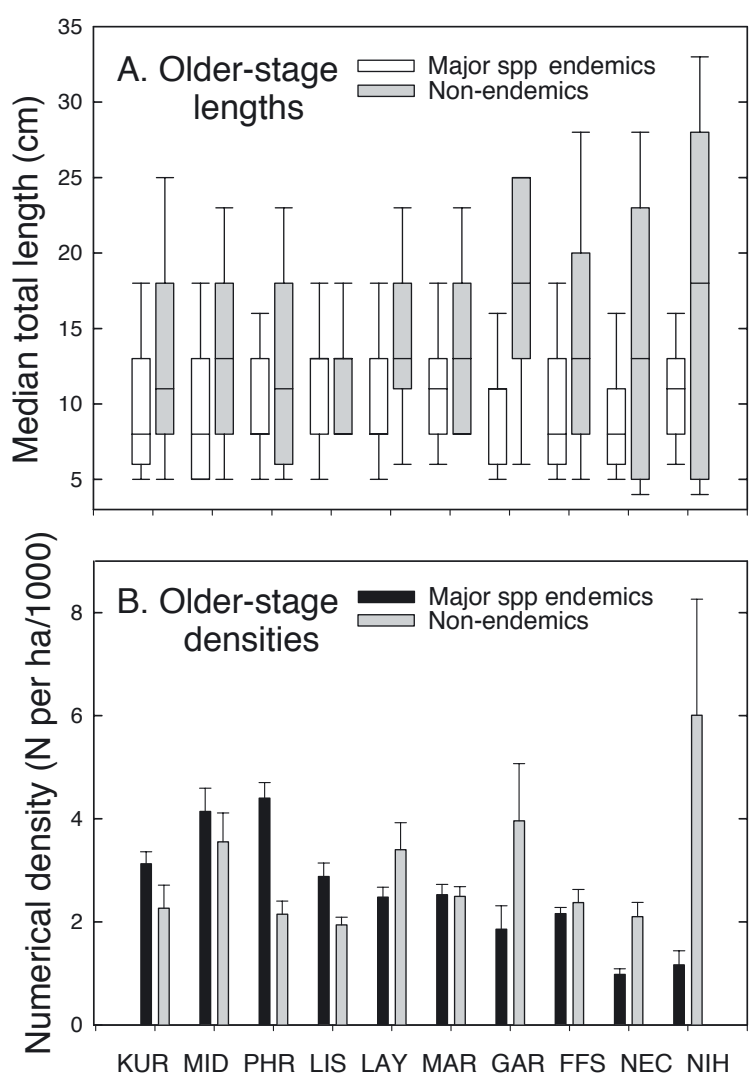

Fig. 7. Geographic patterns of (A) median body lengths (total length [TL] in cm) and (B) mean numerical densities (no. ha ${ }^{-1}$ ) of older-stage fishes, summarized for pooled major species of endemics and non-endemics, at each of the 10 emergent Northwestern Hawaiian Island (NWHI) reefs surveyed during September/October 2000, 2001 and 2002. In (A), median TLs are bounded by first and third quartiles (box) and 10th and 90th percentiles (whiskers). In (B), vertical lines indicate SEs of mean density estimates. See Table 1 for reef abbreviations 
dance data are much less frequently available. For example, in their annotated checklist, Randall et al. (1993) discuss the apparently greater abundance of endemic fishes at Midway Atoll (relative to the MHI) based on casual observations. Early diver-observations of shallow reef fishes in the NWHI were limited in effort (only 2 to 16 transects, each of $100 \mathrm{~m}^{2}$ area, per major reef: Hobson 1984) and were qualitative. More recent studies, although quantitative, were limited to only 2 of the 10 emergent NWHI reefs (FFS, Midway: DeMartini et al. 1996, 2002). Species-presence comparisons in general are further limited by treating all species equally, regardless of varying species abundances, body sizes, or ecological functions within their communities. In this regard our geographic comparisons are unusual for marine fish faunas and unique for the reef fishes of Hawaii. Evaluating the significance of endemism, like other biogeographic and ecological patterns, is more meaningful if data on attributes such as abundance and biomass are available (Bellwood et al. 2002). In the case of Hawaiian reef fishes, abundance data allow detection of geographic pattern that data on species presence do not.

\section{Latitudinal patterns}

Endemism increases with latitude for shallow reef fishes within the NWHI if based on abundance (either numerical or biomass). If the spatial scale is expanded to include the MHI, the gradient strengthens (Table 5).
Species presence-based estimates of endemism using diver-observations were similar for the NWHI and MHI (Table 5). We caution that endemism estimates based solely on visual observations of conspicuous species should not be directly compared with more comprehensive estimates of endemism, based on many additional sources such as market sampling and museum collections that include tiny, cryptic species. The most comprehensive estimate of endemism, based on species presence, for the reef and shore fishes of Hawaii is $23.1 \%$ (Randall 1998). Diver observations nonetheless can be validly compared with themselves, and they indicate that the proportionate abundance of the more conspicuous reef fish endemics increases with latitude in the Hawaiian archipelago.

\section{Body sizes of island endemics}

Like island endemics elsewhere, the endemic fishes of Hawaii are small bodied and have very restricted geographic ranges of $<50000 \mathrm{~km}^{2}$ (Roberts \& Hawkins 1999, Hawkins et al. 2000, Roberts et al. 2002). No strong general relation exists between geographic range and body size, even though few large-bodied species have small ranges (Jones et al. 2002). Small body size per se may be associated with higher extinction risk because small-bodied species tend to have narrower habitat requirements (Hawkins et al. 2000). Therefore both body size and endemic status argue for the conservation of these species.
Table 5. Percentage endemism of reef fishes in the Northwestern Hawaiian Islands (NWHI) and Main Hawaiian Islands (MHI) using in situ diverobservations of species occurrence and estimates of numerical and biomass density. SEs of species presence-based estimates are noted

\begin{tabular}{|c|c|c|c|c|}
\hline Region & Criterion & Type of data & $\begin{array}{l}\text { Percent } \\
\text { endemism }\end{array}$ & Source \\
\hline NWHI & Species presence & Visual surveys & $20.6 \pm 2.5^{\mathrm{a}}$ & This paper \\
\hline NWHI & Numerical density & Visual surveys & $52^{\mathrm{a}}$ & This paper \\
\hline NWHI & Biomass density & Visual surveys & $19^{a}$ & This paper \\
\hline MHI & Species presence & Visual surveys & $20.9 \pm 3.6^{\mathrm{a}, \mathrm{b}}$ & $\begin{array}{l}\text { A. Friedlander } \\
\text { (unpubl data) }\end{array}$ \\
\hline MHI & Numerical density & Visual surveys & $31^{a, b}$ & $\begin{array}{l}\text { A. Friedlander } \\
\text { (unpubl data) }\end{array}$ \\
\hline MHI & Biomass density & Visual surveys & $18^{a, b}$ & $\begin{array}{l}\text { A. Friedlander } \\
\text { (unpubl data) }\end{array}$ \\
\hline MHI & Numerical density & Visual surveys & $35^{\mathrm{a}, \mathrm{c}}$ & $\begin{array}{l}\text { Friedlander } \\
\text { et al. (2003) }\end{array}$ \\
\hline MHI & Biomass density & Visual surveys & $22^{a, c}$ & $\begin{array}{l}\text { Friedlander } \\
\text { et al. (2003) }\end{array}$ \\
\hline \multicolumn{5}{|c|}{ a All fish species observed, including apex predators } \\
\hline \multicolumn{5}{|c|}{$\begin{array}{l}{ }^{\mathrm{b}} \text { Bodianus bilunulatus and Acanthurus triostegus considered non-endemic to } \\
\text { Hawaii, as in present paper }\end{array}$} \\
\hline \multicolumn{5}{|c|}{$\begin{array}{l}{ }^{\mathrm{c} B o d i a n u s} \text { bilunulatus albotaeniatus and Acanthurus triostegus sandwichien- } \\
\text { sis considered sub-specifically endemic to Hawaii }\end{array}$} \\
\hline
\end{tabular}

\section{Environmental influences of endemism}

Geographic relations with endemism include both geologic isolation (distance between populated reef habitat) and oceanographic isolation (direction as well as distance separating reefs), especially for island faunas. Both types of isolation influence dispersal between major sources of recruits to populations (e.g. between archipelagos such as the Line Islands and the Hawaiian Islands) and among local sources of replenishment (e.g. reefs within the Hawaiian archipelago). This is true whether the issue is the evolution of endemism or its subsequent maintenance, although larger-scale factors might be more relevant for the initial development and smaller-scale factors more important for the maintenance of endemism. Both 
distance and direction must be related to the dispersal potential of planktonic stages, although duration of the dispersal stage is a generally poor predictor of geographic range (Jones et al. 2002) and the exact nature and taxonomic distribution of relationships remains obscure. Within the reef fishes of Hawaii, for example, endemic damselfishes (family Pomacentridae) have shorter planktonic durations than non-endemic damselfishes, but no such relationship exists for wrasses (family Labridae) (Cowen \& Sponaugle 1997). The planktonic durations of other groups are poorly documented. With the conspicuous exceptions of only 2 species (the filefish Pervagor spilosoma and bigeye Priacanthus meeki), species with pelagic juveniles that settle at very large $(>5 \mathrm{~cm}$ ) body lengths are unknown among Hawaiian endemics; large pelagic juveniles are primarily restricted to non-endemic mullids, acanthurids, holocentrids, kyphosids, and tetraodontiforms. The known planktonic durations of Hawaiian-reef fishes in fact range from minima of ca. $3 \mathrm{wk}$ in some demersal-spawning pomacentrids (Cowen \& Sponaugle 1997) to maxima of perhaps 6 mo or longer in balistids with extremely large pelagic juvenile stages (e.g. Melichthys niger: Walsh 1984), so a broad range in dispersal potential exists among taxa. The planktonic stages of reef fishes must travel very large geographic distances (both latitude and longitude) to colonize the Hawaiian Islands, if born outside of the archipelago, or to disperse outside of the archipelago, if produced within it (Hourigan \& Reese 1987). However, reef fish populations within the archipelago undoubtedly exchange many propagules every generation between adjacent reefs because of the relatively short distances between neighboring reefs. Low levels of gene flow (5 to 10 individuals per generation: Allendorf \& Phelps 1981) would induce panmixis across the entire Hawaiian archipelago for most species. The overall strength of endemism within the archipelago thus is more a reflection of the great distances and isolation between Hawaii and other island systems than between adjacent reefs within the archipelago. That few species pairs or flocks exist in marine taxa of the archipelago further argues against the isolation of individual reefs; most endemic marine species with known phylogenies have more widespread Indo-Pacific taxa as their sister species (Springer 1982, Randall 1995).

Geomorphological events operating at evolutionary time scales (Ormond \& Roberts 1997) have no doubt strongly contributed to the development of endemic species of coral-reef and other fishes of the Hawaiian Islands. Not surprisingly, we observed endemism to be greatest at the most ancient reefs of the far northwestern end of the archipelago, where species have had the longest period of time to evolve during tectonic drift. For reasons discussed below, we believe that con- temporary factors continue to influence the observed latitudinal patterns of endemism, even though historical factors have undoubtedly been important (Hobson 1994). Some of the non-endemic species abundant at higher latitude reefs in the NWHI have antitropical distributions and are thought to have established themselves in the archipelago when surface waters were previously cooler (Randall 1981). The Hawaiian morwong, for example, may be a cryptic species that diverged during the late Miocene-early Pliocene from the lineage presently represented by nominal conspecifics in the southern hemisphere (Burridge \& White 2000). Interestingly, most Hawaiian endemic species do not exhibit submergence (greater depth distributions) in the MHI, although rigorous comparisons are lacking.

To our knowledge, no analogous evaluation of reef fish endemism (i.e. based on in situ density estimates) exists for any other geographically expansive and isolated island system.

\section{Processes influencing spatial endemism patterns}

Numerous, non-mutually exclusive hypotheses can be invoked to explain the observed co-occurrence of higher recruitment and greater abundance of endemics at higher latitude NWHI reefs. All to a greater or lesser extent depend on the basic assumption that the abundance of adults within populations of marine fishes is generally determined by year-class successes established sometime during the juvenile stage (Sinclair 1988); hence, sustained higher levels of recruitment, greater post-settlement survivorship, or both together should result in a generally larger population size. Of course, we further assume that shortterm observations of pattern accurately reflects underlying evolutionary process. This can only be tested by repeated characterizations of pattern, which we heartily encourage (although we acknowledge that major environmental phenomena resulting from recent human perturbations may not represent the historical environments under which organisms evolved). If, in fact, endemic species are more abundant at higher latitude reefs in the NWHI to some extent because their average long-term rates of replenishment are higher than those of non-endemics, this would represent a rare (if not unique) demonstration that endemics have an evolved capability to be more abundant than non-endemics within any assemblage of organisms, after controlling for the relative numbers of species in the 2 groups.

Predation intensity that differs predictably with latitude might possibly influence patterns of endemism. Consider, for example, the plausible scenario that pis- 
civores at greater abundances are able to more greatly reduce the density of their fish prey (Hixon \& Beets 1993, Beets 1997, Stewart \& Jones 2001). This intuitive argument is not convincing, however, despite some evidence that the abundance of apex predators (that crop the predators of the recruits of fishes in the present study) generally increases farther upchain (Friedlander \& DeMartini 2002). Recruits were not especially abundant at Pearl and Hermes where apex predators were most abundant (Fig. 8) and the predators of recruits were most cropped (DeMartini et al. unpubl). RIs were high at Kure and Midway Atolls (Fig. 5) even though the abundance of apex predators was relatively low (Fig. 8) and the predators of recruits were least cropped at these reefs (DeMartini et al. unpubl). Moreover, in the present study we observed that the pattern of average body sizes of neither endemic nor non-endemic, non-apex predatory reef fishes differed geographically within the NWHI, as might be expected if predation intensities and prey body sizes were inversely related and simply varied with latitude.

Several other, non-mutually exclusive mechanisms might be influencing the spatial distribution patterns of endemism for reef fishes in the NWHI. The first general set of possibilities involves differential transport and dispersal of larvae and pelagic juveniles for endemic versus non-endemic species. One possibility is that endemic species, having more finely adapted to the environment of the archipelago, might have evolved mechanisms of more effective planktonic dispersal and replenishment within reef populations. Differential transport and dispersal as plankton prior to settlement is one possibility. Mechanisms for the former include

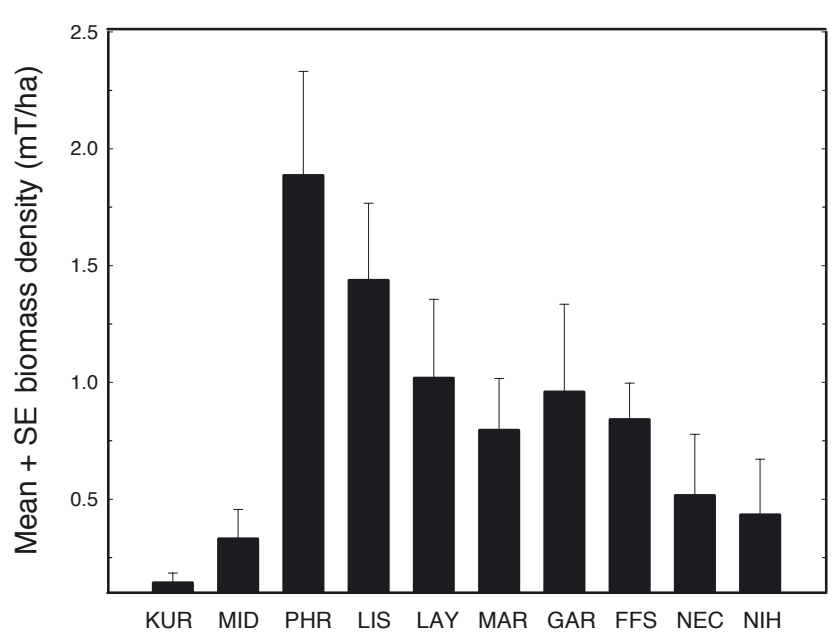

Fig. 8. Geographic pattern of apex predator biomass density $\left(\mathrm{kg} \mathrm{ha}^{-1}\right)$ at the 10 emergent Northwestern Hawaiian Island (NWHI) reefs surveyed during September/October 2000, 2001 and 2002. Vertical lines indicate SEs of mean density estimates. See Table 1 for reef abbreviations higher levels of within-reef and subregional reseeding of planktonic propagules (Swearer et al. 2002) at higher latitudes in the NWHI. Such a possibility would require the existence of some oceanographic or other factor that disproportionately favors retention at the northernmost reefs for endemic populations. Evolved differences between endemics and non-endemics in settling behaviors (swimming capabilities, response to settlement cues) are possible but unknown.

Dichotomous geomorphologies and related water circulation, i.e. restricted circulation within lagoons and transport only through passes at atolls versus greater dispersion away from reef habitats at nonatolls, do not provide a sufficient explanation for putatively greater larval retention at northern NWHI reefs. We observed that percentage endemism was highest in biomass and nearly so in numbers at Lisianski-Neva Shoal (a high latitude non-atoll) whereas endemism at lower-latitude reefs like FFS (a partly drowned atoll) and Maro Reef (an open atoll reef system) was notably less. This is perhaps because lagoons and other wavesheltered areas at atolls do not provide primary spawning habitat, at least for less site-attached and more vagile, larger-bodied species (DeMartini 1998) that migrate to/from passes for spawning, despite the important nursery function of sheltered habitats for post-settlement juveniles (Adams \& Ebersole 2002, DeMartini 2004). For example, among the 41 major taxa evaluated in the present study, only a single species (the endemic domino damselfish Dascyllus albisella) is primarily a lagoonal patch reef species at FFS and at Midway; and all other major species of reef fishes are most abundant in either forereef or backreef habitats at these 2 reefs (DeMartini et al. 2002). Leis et al. (2003) provides an important counter-example: some fish species complete their entire planktonic early life-history within lagoons of closed atolls in the south central Pacific.

Other possible oceanographic mechanisms include greater average (net upchain) transport of planktonic propagules, even if only within the NWHI (and not the entire archipelago including the MHI). Limited data (NOAA Fisheries Service, Pacific Islands Fisheries Science Center, unpubl.) suggest that Ekman flow is greater upchain (mean $=3 \mathrm{~cm} \mathrm{~s}^{-1}$ surface current to the NW). Such a low velocity mean flow, of course, does not deny the possibility that episodic flows in the same (e.g. North Equatorial Current) or other directions (e.g. eddies generated by annually varying, seasonal latitudinal shifts in the Subtropical Front) might provide important transport functions (Cowen 2002). At a unidirectional velocity of $3 \mathrm{~cm} \mathrm{~s}^{-1}$, a passive particle would travel 78 to $156 \mathrm{~km}$ over a 30 to $60 \mathrm{~d}$ period, but fish larvae are not passive particles and the directed swimming of later-stage larvae may either limit or enhance 
the actual distance transported by currents (reviewed by Leis \& McCormick 2002).

Other non-exclusive possibilities are that larval (Bergenius et al. 2002) or post-settlement (Jones 1997, Booth \& Hixon 1999) growth or survivorship are somehow enhanced upchain, resulting in greater average recruitment at the northernmost reefs. One possibility is that the seasonally cooler, more productive oceanic waters at the northern end of the archipelago (Schmelzer 2000) promote faster growth and related better survival for pelagic or early benthic life-stages. Comparisons of larval growth rates and planktonic larval durations (PLDs) between the MHI and NWHI, matched by species, would help resolve whether the mechanism was a pre-settlement phenomenon. It is unclear how endemics would benefit more than nonendemics from faster pre- or post-settlement growth and increased survivorship at the more productive higher latitudes. If an important post-settlement phenomenon were operative on NWHI reefs, though, it is likely restricted to sometime during the first year of life following settlement, because we observed no geographic pattern to the median body sizes or mean densities of the older stages of either endemic or nonendemic species. Greater endemic abundance at higher latitude reefs is not likely to have resulted from a reduced abundance of non-endemics (i.e. competitive release) because the densities of older stage nonendemics were unrelated to latitude. This latter pattern generally held despite the observed absence of a few, broadly distributed Indo-Pacific species (brown surgeonfish Acanthurus nigrofuscus, orangeband surgeonfish A. olivaceus, bigeye emperor Monotaxis grandoculis) at the higher latitude reefs.

Further insights enabling discrimination among these possibilities will require comparative analyses of birthdate distributions, the mean and variance of PLDs, and trace element signatures in otoliths of recent settlers collected from reefs throughout the archipelago, plus improved understanding of ocean circulation patterns and larval distributions. For example, the elemental composition of reef fish otoliths might differ between larvae whose development in MHI waters is burdened by coastal runoffs containing lead, herbicides, and several volcanism-specific elements (Spencer et al. 2000, Sansone et al. 2002), and larvae experiencing the relatively pristine oceanic environments of NWHI waters. Several accurate and precise techniques such as modern mass spectrometry (Campana et al. 2000, Palumbi et al. 2003) exist for quantifying trace element signatures in the tiny otoliths of reef fish settlers. Resolution of these issues will be difficult but would be profoundly important, in particular, to the future siting of no-take MPAs and, more generally, to the rational conservation and sustainable exploita- tion of reef fish resources in the MHI as well as the NWHI.

\section{Implications for marine protected area design}

A major goal of MPAs should be the protection of species having disproportionate ecological importance, such as apex predators that function as keystones in structuring coral reef ecosystems (Carr et al. 2002). The conservation of keystones should have high management priority. Fortunately, only a single species of apex predator in the NWHI is an endemic; this fact, however, underscores the need to determine spawning habitat and conserve habitat and reproductive adults as part of a management plan for the Hawaiian grouper (Friedlander \& DeMartini 2002).

The design of the reserve/sanctuary system in the NWHI, and its related management, moreover should be greatly dependent on whether (and, if so, to what extent) reef fish and other resource populations of the NWHI are reseeded versus open to replenishment from the MHI and elsewhere (Roberts 1998). If, for example, NWHI populations were completely open, stocks spanning the MHI-NWHI should be managed as a single unit and the numbers, siting, and size of MPAs should be chosen to recognize the fact that longer-distance dispersers need larger reserves to maintain sustainability (Botsford et al. 2003). On the other hand, if NWHI populations were reseeded entirely from within the NWHI, smaller, perhaps more numerous, MPAs should be sited in the NWHI so as to conserve spawning stocks within the NWHI, not the entire archipelago. If, as is perhaps most likely, various species differ along a continuum between populations that are slightly reseeded to those that are highly reseeded at a local level, the optimal strategy would be to strike a balance between conserving spawning stocks within and between the 2 regions when siting and designing MPAs. The objectives of a well-designed reserve/sanctuary system in the NWHI should include the conservation of its high levels of endemism and unique biodiversity (Hughes et al. 2002, Roberts et al. 2003), as well as the more conventional MPA goals of fisheries enhancement and protection of spawning stock (Roberts et al. 2001, Sladek-Nowlis \& Friedlander 2004). Fortunately, these 2 goals are largely coincident in situations in which most stocks are unexploited at the time MPAs are established (Hastings \& Botsford 2003). The NWHI would be a prime example-if NWHI populations are not strongly linked with those in the MHI-but we do not know whether this is so. In conclusion, further studies examining connectivity among reef fish populations throughout the Hawaiian Archipelago are greatly needed. 
Acknowledgements. Funding support from NOAAs Coral Reef Conservation Program through the NOAA Fisheries Office of Habitat Conservation and the NOAA Coral Reef Ecosystem Reserve is greatly appreciated. We thank the officers and crew of the NOAA ship 'Townsend Cromwell' and the RV 'Rapture' and our many colleagues in the Coral Reef Ecosystem Division of the Pacific Island Fisheries Science Center for helping to plan and execute the 5 cruises, and especially the many diver-observers (particularly R. Kosaki, W. Walsh, and S. Cotton) for assistance in conducting fish surveys under often-challenging weather and sea conditions. We also gratefully acknowledge D. Yamaguchi for drafting Fig. 1; and R. Brainard, R. Larson, R. Warner, and 2 anonymous reviewers for constructive criticisms of manuscript drafts.

\section{LITERATURE CITED}

Adams AJ, Ebersole JP (2002) Use of back-reef and lagoon habitats by coral reef fishes. Mar Ecol Prog Ser 228: 213-226

Allen GR (2002) Indo-Pacific coral-reef fishes as indicators of conservation hotspots. Proc 9th Int Coral Reef Symp 2: 921-926

Allendorf FW, Phelps SR (1981) Use of allele frequencies to describe population structure. Can J Fish Aquat Sci 38: $1507-1514$

Beets J (1997) Effects of predatory fish on the recruitment and abundance of Caribbean coral reef fishes. Mar Ecol Prog Ser 148:11-21

Bellwood DR, Wainwright PC, Fulton CJ, Hoey A (2002) Assembly rules and functional groups at biogeographical scales. Funct Ecol 16:557-562

Bergenius MAJ, Meekan MG, Robertson DR, McCormick MI (2002) Larval growth predicts the recruitment success of a coral reef fish. Oecologia (Berl)131:521-525

Booth DJ, Hixon MA (1999) Food ration and condition affect early survival of the coral reef damselfish, Stegastes partitus. Oecologia (Berl)121:364-368

Botsford LW, Micheli F, Hastings A (2003) Principles for the design of marine reserves. Ecol Appl 13:S25-S31

Burridge CP, White RWG (2000) Molecular phylogeny of the antitropical subgenus Goniistius (Perciformes: Cheilodactylidae: Cheilodactylus): evidence for multiple transequatorial divergences and non-monophyly. Biol J Linn Soc 70:435-458

Caley MJ, Carr MH, Hixon MA, Hughes TP, Jones GP, Menge B (1996) Recruitment and the local dynamics of open marine populations. Annu Rev Ecol Syst 27:477-500

Campana SE, Chouinard GA, Hanson JM, Frechet A, Brattey $\mathrm{J}$ (2000) Otolith elemental fingerprints as biological tracers of fish stocks. Fish Res 46:343-357

Carr MH, Anderson TW, Hixon MA (2002) Biodiversity, population regulation, and the stability of coral reef fish communities. Proc Natl Acad Sci USA 99:11241-11245

Chave EH, Malahoff A (1998) In deeper waters: photographic studies of Hawaiian deep-sea habitats and life-forms. University of Hawaii Press, Honolulu

Conover WJ, Iman RL (1981) Rank transformation as a bridge between parametric and non-parametric statistics. Statistician 35:124-133

Cowen RK (2002) Larval dispersal and retention and consequences for population connectivity. In: Sale PF (ed) Coral reef fishes: dynamics and diversity in a complex ecosystem. Academic Press, San Diego, p 149-170

Cowen RK, Sponaugle S (1997) Relationships between early life history traits and recruitment among coral reef fishes.
In: Chambers RC, Trippel EA (eds) Early life history and recruitment in fish populations. Chapman \& Hall, London, p 423-449

DeMartini EE (1998) How might recruitment research on coral-reef fishes help manage tropical reef fisheries? Aust J Ecol 23:305-310

DeMartini EE (2004) Habitat and endemism of recruits to shallow reef fish populations: selection criteria for no-take MPAs in the NWHI Coral Reef Ecosystem Reserve. Bull Mar Sci 14:185-205

DeMartini EE, Parrish FA, Parrish JD (1996) Interdecadal change in reef fish populations at French Frigate Shoals and Midway Atoll, Northwestern Hawaiian Islands: statistical power in retrospect. Bull Mar Sci 58:804-825

DeMartini EE, Parrish FA, Boland RC (2002) Comprehensive evaluation of shallow reef fish populations at French Frigate Shoals and Midway Atoll, Northwestern Hawaiian Islands (1992/93, 1995-2000). NOAA Technical Memorandum NOAA-TM-NMFS-SWFSC-347NOAA Fisheries, Southwest Fisheries Science Center, Honolulu

Doherty PJ (2002) Variable replenishment and the dynamics of reef fish populations. In: Sale PF (ed) Coral reef fishes: dynamics and diversity in a complex ecosystem. Academic Press, San Diego, p 327-355

Friedlander AM, DeMartini EE (2002) Contrasts in density, size, and biomass of reef fishes between the northwestern and the main Hawaiian Islands: the effects of fishing down apex predators. Mar Ecol Prog Ser 230:253-264

Friedlander AM, Brown, EK, Jokiel PL, Smith WR, Rodgers KS (2003) Effects of habitat, wave exposure, and marine protected area status on coral reef fish assemblages in the Hawaiian archipelago. Coral Reefs 22:291-305

Gauch HG Jr (1982) Multivariate analysis in community ecology. Cambridge University Press, Cambridge

Hastings A, Botsford LW (2003) Comparing designs of marine reserves for fisheries and for biodiversity. Ecol Appl 13:S65-S70

Hawkins JP, Roberts CM, Clark V (2000) The threatened status of restricted range coral reef fish species. Anim Conserv 3:81-88

Hixon MA, Beets JP (1993) Predation, prey refuges, and the structure of coral reef fish assemblages. Ecol Monogr 63: 77-101

Hixon MA, Webster MS (2002) Density dependence in reef fish populations. In: Sale PF (ed) Coral reef fishes: dynamics and diversity in a complex ecosystem. Academic Press, San Diego, p 303-325

Hobson ES (1984) The structure of reef fish communities in the Hawaiian Archipelago. In: Grigg R, Tanoue K (eds) Proc 2nd Symp Resource Investigations in the Northwestern Hawaiian Islands, Vol 1. UNIHI-SEA GRANT-MR84-01, University of Hawaii Sea Grant College Program, Honolulu, p 101-122

Hobson ES (1994) Ecological relations in the evolution of acanthopterygian fishes in warm-temperate communities of the northeastern Pacific. Environ Biol Fish 40:49-90

Hourigan TF, Reese ES (1987) Mid-ocean isolation and the evolution of Hawaiian reef fishes. Trends Ecol Evol 2: 187-191

Hughes TP, Bellwood DR, Connolly SR (2002) Biodiversity hotspots, centers of endemicity, and the conservation of coral reefs. Ecol Lett 5:775-784

Jones GP (1997) Relationships between recruitment and postrecruitment processes in lagoonal populations of two coral reef fishes. J Exp Mar Biol Ecol 213:231-246

Jones GP, Caley MJ, Munday PL (2002) Rarity in coral reef fish communities. In: Sale PF (ed) Coral reef fishes: 
dynamics and diversity in a complex ecosystem. Academic Press, San Diego, p 81-101

Juvik SP, Juvik JO (1998) Atlas of Hawaii, 3rd edn. University of Hawaii Press, Honolulu

Kovach WL (1995) MVSP-a multivariate statistical package for IBM PC's. V. 2.2. Kovach Computing Services, Pentraeth, Wales

Leis JM, McCormick MI (2002) The biology, behavior and ecology of the pelagic, larval stage of coral reef fishes. In: Sale PF (ed) Coral reef fishes: dynamics and diversity in a complex ecosystem. Academic Press, San Diego, p 171-199

Leis JM, Trnski T, Dufour V, Harmelin-Vivien M, Renon JP, Galzin R (2003) Local completion of the pelagic larval stage of coastal fishes in coral-reef lagoons of the Society and Tuomotu Islands. Coral Reefs 22:271-290

Manly BFJ (1991) Randomization and Monte Carlo methods in biology. Chapman \& Hall, New York

Mora C, Sale PF (2002) Are populations of coral reef fish open or closed? Trends Ecol Evol 17:422-428

Ormond RFG, Roberts CM (1997) The biodiversity of coral reef fishes. In: Ormond RFG, Gage JD, Angel MV (eds) Marine biodiversity: patterns and processes. Cambridge University Press, New York, p 216-257

Palumbi SR (2003) Population genetics, demographic connectivity, and the design of marine reserves. Ecol Appl 13:S146-S158

Palumbi SR, Gaines SD, Leslie H, Warner RR (2003) New wave: high tech tools to help marine reserve research. Frontier Ecol 1:73-79

Randall JE (1981) Examples of antitropical and antiequatorial distribution of Indo-West-Pacific fishes. Pac Sci 35: 197-209

Randall JE (1995) Zoogeographic analysis of the inshore Hawaiian fish fauna. In: Maragos JE, Peterson MNA, Eldredge LG, Bardach JE, Takeuchi HF (eds) Marine and coastal biodiversity in the tropical island Pacific region: Vol. 1, Species systematics and information management priorities. East-West Center, Honolulu, p 193-203

Randall JE (1996) Shore fishes of Hawaii. Natural World Press, Vida

Randall JE (1998) Zoogeography of shore fishes of the IndoPacific region. Zool Stud (Taiwan) 37:227-268

Randall JE, Clements KD (2001) Second revision of the surgeonfish genus Ctenochaetus (Perciformes: Acanthuridae), with descriptions of two new species. Indo-Pacific Fishes, Bishop Museum (Honolulu) (32):1-33

Randall JE, Earle JL (2000) Annotated checklist of the shore fishes of the Marquesas Islands. Occas Pap Bishop Museum 66:1-39

Randall JE, Myers RF (2002) Parupeneus insularis, a new central Pacific species of goatfish (Perciformes: Mullidae) of the $P$. trifasciatus complex. Zool Stud (Taiwan) 41:431-440

Randall, JE, Earle JL, Pyle RL, Parrish JD, Hayes T (1993) Annotated checklist of the fishes of Midway Atoll, Northwestern Hawaiian Islands. Pac Sci 47:356-400

Roberts CM (1998) Sources, sinks and the design of marine reserve networks. Fisheries 23:16-19

Editorial responsibility: Charles Birkeland (Contributing Editor), Honolulu, Hawaii, USA
Roberts CM, Hawkins JP (1999) Extinction risk in the sea. Trends Ecol Evol 14:241-246

Roberts CM, Bohnsack JA, Gell F, Hawkins JP, Goodridge R (2001) Effects of marine reserves on adjacent fisheries. Science 294:1920-1923

Roberts CM, McClean CJ, Veron JEN, Hawkins JP and 8 others (2002) Marine biodiversity hotspots and conservation priorities for tropical reefs. Science 295:1280-1284

Roberts CM, Andelman S, Branch G, Bustamante RH and 10 others (2003) Ecological criteria for evaluating candidate sites for marine reserves. Ecol Appl 13:S199-S214

Robertson DR (2001) Population maintenance among tropical reef fishes: inferences from small-island endemics. Proc Natl Acad Sci USA 98:5667-5670

Sansone FJ, Benitez-Nelson CR, Resing JA, DeCarlo EH, Vink, SM, Heath JA, Huebert BJ (2002) Geochemistry of atmospheric aerosols generated from lava-seawater interactions. Geophys Res Lett 29:49-1 to 49-4

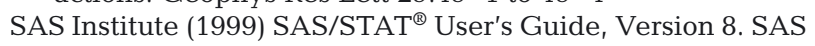
Institute, Cary, NC

Schmelzer I (2000) Seals and seascapes: covariation in Hawaiian monk seal subpopulations and the oceanic landscape of the Hawaiian Archipelago. J Biogeogr 27:901-914

Shaklee JB (1984) Genetic variation and population structure in the damselfish, Stegastes fasciolatus, throughout the Hawaiian Archipelago. Copeia 1984:629-640

Siegel S, Castellan JJ Jr (1988) Nonparametric statistics for the behavioral sciences, 2nd edn. McGraw-Hill, New York

Sinclair M (1988) Marine populations: an essay on population regulation and speciation. Washington SeaGrant Program, University of Washington, Seattle

Sladek-Nowlis J, Friedlander AM (2004) Marine reserve design and function for fisheries management. In: Norse EA, Crowder LB (eds) Marine conservation biology: the science of maintaining the sea's biodiversity. Island Press, Washington, DC

Spencer K, Shafer DJ, Gauldie RW, DeCarlo EH (2000) Stable lead isotope ratios from distinct anthropogenic sources in fish otoliths: a potential nursery ground stock marker. Comp Biochem Physiol Part A 127:273-284

Springer V (1982) Pacific plate biogeography, with special reference to shore fishes. Smithson Contrib Zool 367: 1-182

Stewart BD, Jones GP (2001) Associations between the abundance of piscivorous fishes and their prey on coral reefs: implications for prey-fish mortality. Mar Biol 138:383-397

Swearer SE, Shima JS, Hellberg ME, Thorrold SR and 6 others (2002) Evidence of self-recruitment in demersal marine populations. Bull Mar Sci 70(1):251-271

Victor BC, Wellington GM (2000) Endemism and the pelagic larval duration of reef fishes in the eastern Pacific Ocean. Mar Ecol Prog Ser 205:241-248

Walsh WJ (1984) Aspects of nocturnal shelter, habitat space, and juvenile recruitment in Hawaiian coral reef fishes. PhD thesis, University of Hawaii, Honolulu

Wellington GM, Victor BC (1992) Regional differences in duration of the planktonic larval stage of reef fishes in the eastern Pacific Ocean. Mar Biol 113:491-498

Submitted: September 16, 2003; Accepted: January 2, 2004 Proofs received from author(s): April 3, 2004 